\title{
Integrált optikai szenzor biológiai minták gyors analíziséhez
}

\author{
Mathesz Anna ${ }^{1}$ - Valkai Sándor dr. ${ }^{1}$ - Sipos Orsolya ${ }^{1}$ - Stercz Balázs ${ }^{2}$ \\ Kocsis Béla dr. ${ }^{2}$ - Szabó Dóra dr. ${ }^{2}$. Dér András dr. ${ }^{1}$ \\ ${ }^{1}$ MTA Szegedi Biológiai Kutatóközpont, Biofizikai Intézet, Szeged \\ ${ }^{2}$ Semmelweis Egyetem, Általános Orvostudományi Kar, Orvosi Mikrobiológiai Tanszék, Budapest
}

Bevezetés: A patogén baktériumok orvosi diagnosztikájában az egyik legfontosabb elvárás a kórokozók minél gyorsabb érzékelése és azonosítása. A legtöbb modern módszer a kimutatni kívánt baktériumokhoz specifikusan kötött, jól detektálható jelölőmolekulák alkalmazásán (érzékelésén) alapul. Ez azonban erősen idő- és költségigényes, többlépcsős folyamat. (A széles körben alkalmazott enzimkapcsolt immunszorbent assay technika például általában 5 technológiai lépést használ.) A gyorsabb és költséghatékonyabb módszerek iránti igény hívta életre az úgynevezett jelölésmentes technikákat. Célkitüzés: Jelen dolgozatban a szerzők által kifejlesztett, baktériumok és biomolekulák jelölésmentes érzékelésére szolgáló integrált optikai eszközt mutatnak be. Módszer: Az eszköz lelke egy polimerszálakból üveglemezre épített, nagy érzékenységű Mach-Zehnder-interferométer. Ezt mikrofluidikai csatornával kombinálva olyan eszközt készítettek, amely - csekély mennyiségű antitest felhasználásával funkcionalizálva - alkalmassá tehető baktériumok gyors, specifikus érzékelésére kis térfogatú folyadékmintából. Eredmények: Eddigi kísérleteik szerint az eszköz néhány perc alatt képes az Escherichia coli baktérium $10^{6} \mathrm{cfu} / \mathrm{ml}$ (telepképző egység/ml) koncentrációjának érzékelésére. Következtetések: A módszer a funkcionalizálás változtatásával (más antitestek használatával) elvileg különböző baktériumok vagy biomolekulák érzékelésére is használható, széles körű alkalmazási lehetőségeket teremtve az orvosi mikrobiológiában, patológiában, bünügyi helyszíneléseknél, környezetvédelmi vizsgálatokban vagy akár a bioterrorizmussal kapcsolatos helyzetekben is. Orv. Hetil., 2015, 156(52), 2116-2119.

Kulcsszavak: bioszenzor-technikák, optikai eszközök, betegágy melletti mérőrendszerek

\section{Integrated optical sensor for rapid analysis of biological samples}

Introduction: In the medical diagnostics of bacteria, the rapid detection of pathogenic microorganisms from body fluids is one of the most important tasks. The majority of the modern measuring techniques are based on specific labels bound to the bacteria. However, this strategy usually assumes a rather time-consuming procedure involving several steps (e.g., the widely used enzyme-linked immunosorbent assay normally consists of 5 consecutive steps). Hence, there is an urgent need for the elaboration of rapid, "label-free" techniques, that are often based on Lab-ona-chip devices. Aim: In this paper, the authors report on the development of a biosensor based on a miniature, integrated optical Mach-Zehnder interferometer. Method: Functionalization of the measuring arm of the sensor by antibodies, made the rapid and specific label-free detection of pathogens feasible. Results: Using the combination of the interferometer with a microfluidic system, the device was able to detect Escherichia coli bacteria at concentrations as low as $10^{6}$ colony forming unit/ml within minutes. Conclusions: This makes the newly developed biosensor a promising device for a wide range of applications, not only in medical microbiology, but microbial forensics, criminal investigations, bio-terrorism threats and in environmental studies as well.

Keywords: biosensing technics, optical devices, point-of-care systems

Mathesz, A., Valkai, S., Sipos, O., Stercz, B., Kocsis, B., Szabó, D., Dér, A. [Integrated optical sensor for rapid analysis of biological samples]. Orv. Hetil., 2015, 156(52), 2116-2119.

(Beérkezett: 2015. október 5; elfogadva: 2015. október 29.) 


\section{Rövidítések}

BSA = borjúszérum-albumin; cfu = telepképző egység; DLW = lézeres rajzolás; ELISA = immunfelismerésen alapuló fehérjeanalitikai elemzőmódszer; MZI = Mach-Zehnder-interferométer; $\mathrm{OD}=1 \mathrm{~cm}$-es vastagságú minta extinkciója; $\mathrm{PBS}=$ foszfátpufferes fiziológiás sóoldat; PDMS = poli-dimetil-sziloxán

Az idő az élet számos területén meghatározó tényező, jelentősége talán mégis az orvostudományban érzékelhető a leginkább. Itt elég egy idejében felállított diagnózis akár életmentô szerepére gondolni. Ezért például a baktériumok gyors kimutatása testfolyadékokból a mikrobiológiai diagnosztikában rendkívül fontos feladat [1]. A mihamarabb elvégzett fajmeghatározás az elkezdett empirikus antibiotikum-terápiát is meghatározza. Azonban a humán mintákból a baktériumok kitenyésztése - fajonként változóan, de - legalább egy napot vesz igénybe, és ezt követi az azonosítás, valamint az antibiotikum-érzékenység meghatározása.

Ez a fó oka annak, hogy egyre több kutatócsoport foglalkozik olyan bioszenzorok fejlesztésével, amelyek megbízhatóan, megfelelő érzékenységgel, rövid idő alatt képesek eredményt szolgáltatni, ugyanakkor előállításuk olcsó és akár orvosi közremúködés nélkül, a beteg otthonában is használhatóak [2]. Jelenleg a legérzékenyebb bioszenzorok többsége jelölésen (például fluoreszcens, radioaktív vagy mágneses jelölésen) alapul, a jelölőanyagot követve akár egy molekulát is képesek kimutatni a vizsgált térfogatban vagy felületen [3]. Elvitathatatlan előnyeiken túl azonban ezek a vizsgálati módok több hátránnyal is rendelkeznek a jelölésmentes technikákkal szemben. A jelöléshez szükséges kémiai eljárások növelik a vizsgálat bonyolultságát, idejét és költségeit, továbbá a jelölő́anyagok nem elhanyagolható hatást gyakorolhatnak a jelölt molekulákra. Többek között e hátrányok miatt a figyelem egyre inkább a jelölésmentes technológiákra, fóként az optikai eljárásokra irányul. Fontos irányvonalat képviselnek ezen a területen az integrált optikai bioszenzorok, azon belül pedig az interferometrikus elven múködő megoldások. Az interferencia jelenségén alapuló szenzorok egyik nagy előnye, hogy rendkívül érzékenyek a felületükön bekövetkező törésmutató-válto- zásokra, azonban ez a nagyfokú érzékenység nemcsak a vizsgálni kívánt biológiai anyag jelenlétébőll, hanem a környezeti hatásokból (hőmérséklet, páratartalom stb.) eredő törésmutató-változásokra is igaz. A páratartalom, illetve hőmérséklet inhomogén változása a kilépő intenzitás folyamatos ingadozását eredményezi, ezáltal akadályozva a bioszenzor pontos és stabil múködését.

Munkánk célja olyan - specifikus felismerésen alapuló - chiplaboratóriumi módszer fejlesztése volt, amely lehetőséget nyújthat különféle baktériumok gyors, jelölésmentes kimutatására, így nagymértékben lerövidítve a diagnosztikai folyamatot. Ennek szellemében olyan integrált optikai Mach-Zehnder-interferométeren alapuló bioszenzort fejlesztettünk ki, amelyet mikrofluidikai rendszerrel kombináltunk. A szenzort E. coli baktériumok kimutatásán keresztül teszteltük.

\section{Módszer}

Közvetlen lézerírásos (DLW) technikával $[4,5]$ integrált optikai Mach-Zehnder-interferométert (MZI) állítottunk elő egymódusú, fotopolimer hullámvezetőkből, transzlációs optikai asztallal felszerelt inverz mikroszkópos elrendezés segítségével. A miniatúr MZI-t üveg hordozófelületre felvitt vékony rétegü fényérzékeny filmbe (NOA81) polimerizáltuk a mikroszkópobjektív által fókuszált kék lézerfény segítségével oly módon, hogy a számítógéphez kötött asztalt mozgattuk - Labview programban definiált pályán - az MZI-struktúra kirajzolása céljából (1. A ábra). A kész MZI mindkét kivezetéséhez egymódusú optikai szálakat csatlakoztattunk (1. B ábra), amelyek közül az egyikbe (bemenet) diódalézer fókuszált nyalábját csatoltuk be mérőfény gyanánt, a másik szál végét pedig a detektor szerepét betöltő fotoelektron-sokszorozóhoz illesztettük, amelynek jeleit oszcilloszkóppal detektáltuk [6].

$\mathrm{Az}$ interferométer két ága köré ezután mikrofluidikai csatornákat építettünk. A csatornákat úgy készítettük, hogy az SU-8 fotoreziszt vékony rétegbe exponált öntóformák előhívása és a nem exponált réteg eltávolítása után az öntőformákat poli-dimetil-sziloxánnal (PDMSsel) öntöttük ki, majd a PDMS-t hókezeléssel fixáltuk, és

B

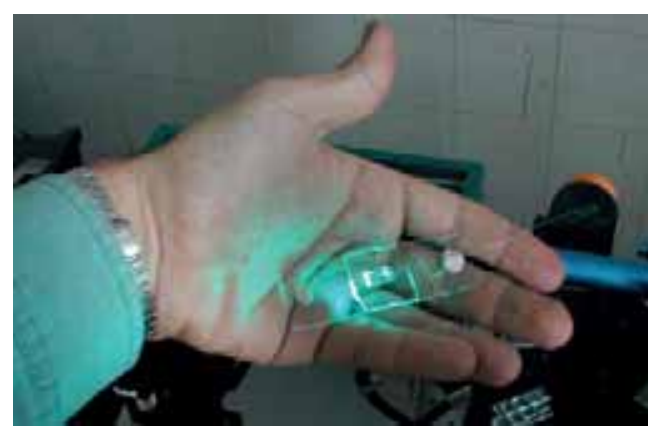


az öntőformákról leválasztottuk. Az így elkészült mikrofluidikai csatornákat - az adhézió elősegítésére - oxigénplazmával kezeltük, majd az interferométerhez rögzítettük. A csatornák be- és kimeneteit képező lyukakba vékony szilikongumi csöveket csatlakoztattunk, ezekbe pedig fecskendőpumpa segítségével adagoltuk a megfelelö folyadékot.

$\mathrm{Az}$ interferométer mérókarjának funkcionalizálását az Escherichia coli baktériumokra kecskében termelt poliklonális antitestekkel végeztük úgy, hogy a mérőkart az antitesteket tartalmazó oldattal 2 órán keresztül inkubáltuk, majd az interferométer antitestekkel le nem fedett felületeit mind a mérőkaron, mind pedig a referenciaágon borjúszérum-albumin- (BSA-) szuszpenzióval kezeltük a vizsgálandó baktériumsejtek nem specifikus adszorpciójának elkerülése végett. A felesleges BSA-t semleges foszfát pufferoldattal (PBS) távolítottuk el. Ezután az interferométer mindkét karjára PBS-oldattal hígított baktériumszuszpenziót pumpáltunk, és az eseményeket az interferométer kimeneti jelein, valamint mikroszkóp segítségével is követtük.

Az E. coli Dh5-alfa törzs telepeit Müller-Hinton agartáptalajon tenyésztettük $37^{\circ} \mathrm{C}$-on. A kísérletek megkezdése előtt egy telepet $3 \mathrm{ml}$ Luria tápoldatban szuszpendáltuk steril polisztirol edényben, majd a baktériumokat $37{ }^{\circ} \mathrm{C}$-on szaporítottuk 18 órán keresztül. Másnap a baktériumszuszpenziót 100-szorosára hígítva a sejteket addig szaporítottuk, amíg a szuszpenzió el nem érte a kívánt sürüséget $(\mathrm{OD}=0,5-0,8,600 \mathrm{~nm})$. Ezután a sejtszuszpenzió 1 ml-ét centrifugálással $(3000 \mathrm{rpm}, 10$ perc) sûrítettük, majd PBS-oldatban reszuszpendáltuk.

$\mathrm{Az}$ ELISA-lemezeket (R\&D Systems, Cat. No.: DY994) $4{ }^{\circ} \mathrm{C}$-on inkubáltuk különféle töménységű $E$. coli-szuszpenziókkal $\left(10^{1}-10^{6}\right.$-szoros hígítás, 0,5\%-os formaldehid [Reanal, 10492-1-01-65] jelenlétében, illetve a nélkül). Lemosás után a felületeket 1\%-os BSA-val (bovine serum albumin, Sigma, Cat. No.: A-6793) kezeltük szobahőmérsékleten 2 órán keresztül, majd háromszor mostuk Tween20 (Sigma, Cat. No.: 93773) 0,05\%-os PBS oldatával. Az elsődleges E. coli-antitesteket 1 , illetve $2 \mu \mathrm{g} / \mathrm{ml}$-es koncentrációban adagoltuk a felületre, egyórás inkubációs idővel. Tween 20-as mosás után a lekötődött antitesteket peroxidázzal jelölt, nyúlban termeltetett anti-kecske-IgG-antitestekkel (SigmaAldrich, Cat. No.: A5420) detektáltuk 40 000-szeres hígításban. Ismételt Tween 20-as mosás után hozzáadtuk a szubsztrátot (Abcam, Cat. No.: ab171522), majd 25 perc elteltével $2 \mathrm{~N}$ kénsavval (R\&D Systems, Cat. No.: DY994) megállítottuk a reakciót, és $450 \mathrm{~nm}$-en (690 nm-es referenciaszürőt használva) megmértük a lemezek abszorpcióját. Kísérleteink igazolták, hogy a vizsgált anti-E. coli-antitest képes kötődni az alkalmazott antigénhez, illetve azt, hogy a kitapadó elsődleges antitestek mennyisége azok koncentrációjától, a bevonó puffertől és a lemezen lévő antigének mennyiségétől függ. Az OD (optikai denzitás, amely a baktériumok koncentrációjával arányos) nagyobb volt magasabb koncentráci- ójú anti-E. coli-antitestek, illetve nagyobb mennyiségü antigén használata esetén. Azt tapasztaltuk továbbá, hogy a formaldehid segítette az E. coli-antigéneknek a felülethez történő kitapadását.

\section{Eredmények}

Az integrált optikai Mach-Zehnder-interferométeres méréseknél az eszközön először az ELISA-kísérleteknél alkalmazott funkcionalizálást végeztük el, majd közvetlenül a mérés előtt az interferométer optikai munkapontját úgy állítottuk be, hogy a lehető legnagyobb érzékenységet kapjuk [4], és ezzel a rendszer készen állt a mérés végrehajtására. Méréskor az E. coli-szuszpenziót a funkcionalizált hullámvezető feletti mérôcsatornába juttattuk, és regisztráltuk az interferométer kimenetén mérhető lézerintenzitást. A bejuttatás időpontjához tartozott a $\mathrm{t}=0$ időpont. A 2. ábra grafikonja mutatja a lézerintenzitás időbeli változását.

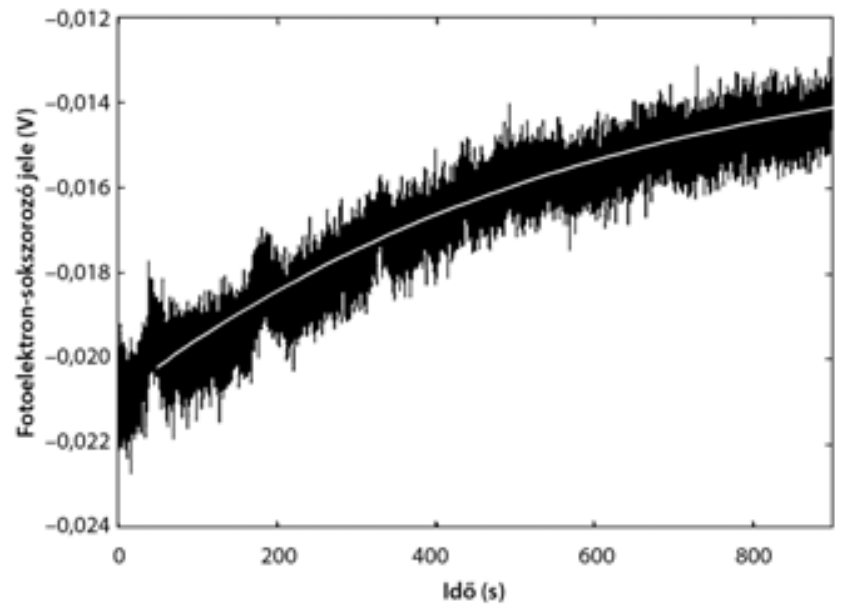

2. ábra

A Mach-Zehnder-interferométer kimenetén megjelenő lézerin tenzitással arányos jel az idő függvényében. A vízszintes időtengely kezdópontja az E. coli baktériumok mérőoldali csatornába töltésének pillanata

A mérési pontokra jól illeszkedik egy exponenciális görbe körülbelül 600 másodperces időállandóval, amely a baktériumok kitapadásának sebességét jellemzi. Ez az időállandó jó egyezést mutat korábbi - ugyancsak baktériumok szilárd felülethez tapadását vizsgáló - tanulmányokban közölt értékekkel [7, 8]. Fontos megjegyeznünk, hogy a tapasztalt kitapadási ráta arányos a baktériumok koncentrációjával. Kísérleteinkben $10^{6} \mathrm{cfu} / \mathrm{ml}$ koncentrációt használtunk, amely a nyálban és vizeletben mérhető jellemző patológiás koncentrációk nagyságrendjébe esik [9, 10], így az eszköz ezeknek a testnedveknek a monitorozására alkalmas lehet. Vérben a baktériumok patológiás koncentrációja nem több, mint $10^{3} \mathrm{cfu} / \mathrm{ml}$, 
ezért vérvizsgálatra az eszköz jelen formájában még nem alkalmas, ehhez az érzékenység növelését célzó további fejlesztésekre van szükség.

\section{Megbeszélés}

Az eszköz nagy előnye, hogy a baktériumok kitapadásának folyamata nyomon követhető és mérhető, pusztán a kimenő optikai jel időbeli változásának elemzésével, anélkül, hogy mikroszkópot kellene használni. Másik hasznos tulajdonsága, hogy a rendszer múködtetése - beleértve a minta bejuttatását, a mérési eredmények rögzítését és feldolgozását - teljesen automatizálható. Az integrált optika és a mikrofluidika együttes alkalmazásából adódó kis méret és csekély áramfelvétel lehetővé teszi az eszköz hordozható verziójának elkészítését is. Ez természetesen magában foglalja az interferométer megfelelő „bedobozolását”, ami egyúttal lehetőséget teremt a hőmérséklet és a páratartalom pontos beállítására is. Ugyancsak előnyös, hogy az eszköz nagyon olcsó anyagokból kis költséggel elóállítható, így csak egyszer használatos jellegú, nem szükséges az újrasterilizálása. Az előbbiekben felsorolt tulajdonságai miatt a jövőben nagy hasznát vehetik például terepen végzett vizsgálatoknál, esetleg szerencsétlenségek, katasztrófák vagy akár bioterrorizmus gyanúját felvető esetek helyszínein is.

Anyagi támogatás: A közleményben ismertetett munka a Bionikai Innovációs Központ támogatásával valósult meg.

Szerzői munkamegosztás: M. A., V. S.: A mikrostruktúra építése, a mérések kivitelezése. S. O.: Minta-előkészítés. S. B., K. B.: Az ELISA-módszerrel történő tesztmérések. Sz. D., D. A.: A projekt megtervezése, a munkafolyamatok irányítása. A cikk végleges változatát valamenynyi szerző elolvasta és jóváhagyta.

Érdekeltségek: A szerzőknek nincsenek érdekeltségeik.

\section{Köszönetnyilvánítás}

A szerzők köszönetüket fejezik ki Mátyus Péter (Semmelweis Egyetem), Tóth Zsuzsanna (Semmelweis Egyetem) és Ormos Pál (Szegedi Biológiai Kutatóközpont) professzoroknak az inspiráló beszélgetésekért, és a kivitelezés során nyújtott értékes tanácsaikért.

\section{Irodalom}

[1] Gilbert, D. N., Spellberg, B., Bartlett, J. G.: An unmet medical need: rapid molecular diagnostics tests for respiratory tract infections. Clin. Infect. Dis., 2011, 52(Suppl. 4), S384-S395.

[2] Bissonnette, L., Bergeron, M. G.: Infectious disease management through point-of-care personalized medicine molecular diagnostic technologies. J. Pers. Med., 2012, 2(2), 50-70.

[3] Abubakar, I., Irvine, L., Aldus, C. F., et al.: A systematic review of the clinical, public health and cost-effectiveness of rapid diagnostic tests for the detection and identification of bacterial intestinal pathogens in faeces and food. Health Technol. Assess., 2007, 11(36), 1-216.

[4] Dér, A., Valkai, S., Mathesz, A., et al.: Protein-based all-optical sensor device. Sensors and Actuators B, 2010, 151(1), 26-29.

[5] Galajda, P., Ormos, P.: Complex micromachines produced and driven by light., Appl. Phys. Lett., 2001, 78(2), 249-251.

[6] Dér, A., Valkai, S., Fábián, L., et al.: Integrated optical switching based on the protein bacteriorhodopsin. Photochem. Photobiol., 2007, 83(2), 393-396.

[7] Ramsden, J. J., Li, S. Y., Heinzle, E., et al.: Optical method for measurement of number and shape of attached cells in real time. Cytometry, 1995, 19(2), 97-102.

[8] Horváth, R., Pedersen, H. C., Skivesen, N., et al.: Optical waveguide sensor for on-line monitoring of bacteria. Optics Lett., 2003, 28(14), 1233-1235.

[9] Miravitlles, M., Marín, A., Monsó, E., et al.: Colour of sputum is a marker for bacterial colonisation in chronic obstructive pulmonary disease. Respir. Res., 2010, 11, 58.

[10] Wilson, M. L., Gaido, L.: Laboratory diagnosis of urinary tract infections in adult patients. Clin. Infect. Dis., 2004, 38(8), $1150-1158$. 